\title{
A Comparative Study of the Experience of Boredom in the L2 and L3 Classroom
}

\section{第二語言和第三語言課堂中無聊情緒的比較研究}

\section{Mariusz Kruk $^{1}$ (D) - Joanna Zawodniak ${ }^{1}$}

Received: 27 March 2019 /Revised: 5 May 2020 / Accepted: 14 May 2020 /

Published online: 13 July 2020

(C) The Author(s) 2020

\begin{abstract}
This study investigates whether there is a significant difference in experiencing boredom between the L2 and L3 classroom. It begins with a comparison between L2 and L3 acquisition, after which the phenomenon of boredom is highlighted, including its definition, typology, causes, and related research. This is followed by a description of the study intended to qualitatively and quantitatively examine the English majors' perceptions of boredom in learning the L2 (English) and the L3 (German). Gathered data enabled the authors to comparatively approach changes in the levels of boredom in the L2 and L3 classroom as well as single out the factors responsible for student boredom in those two learning contexts. The main contributors to this problematic condition encompassed, among others, insufficient teacher engagement, the repeated use of the same teaching tools, uninteresting topics, and a lack of meaning in learning. Although the feelings of L2 and L3 boredom were not found to significantly differ, the overall level of this experience turned out to be higher in the L2 classroom. Finally, the authors formulate their own definition of boredom based on the analysis of obtained results and propose a handful of pedagogical implications.
\end{abstract}

\section{摘要}

本研究探討在第二語言(L2)和第三語言(L3)課堂中, 學生感受無聊的程度是否存在著顯著差 異。本研究首先比較學習L2和L3的不同, 之後說明了何謂無聊情緒, 包括其定義、類型、原因 及相關研究。隨後詳述了本研究如何從質化和量化的角度探究英語系學生在學習L2 (英語) 和 L3 (德語) 時對無聊的感受。透過所收集的資料, 作者得以探究並比較L2和L3課堂中, 學生無聊 情緒在程度上的變化, 並找出導致學生在這兩種學習環境中感受到無聊的因素。結果顯示, 造成 學生產生無聊情緒的主因包括 : 教師投入程度不足、重複的教學方式、無趣的主題、和缺乏學 習意義等。雖然學生對L2和L3課堂產生的無聊情緒在程度上沒有明顯的差異, 但整體而言, 學

Mariusz Kruk

mkruk@uz.zgora.pl

Joanna Zawodniak

j.zawodniak@in.uz.zgora.pl

1 English Department, University of Zielona Góra, Wydział Humanistyczny, al. Wojska Polskiego 71a, 65-762 Zielona Góra, Poland 
生對 $\mathrm{L} 2$ 課堂感到無聊的程度較高。最終, 作者基於現有的分析結果, 針對無聊情緒提出了自身的 定義, 並提供了幾點教學啟示。

Keywords Boredom · Dis/engagement · Fluctuations in the levels of boredom · L2 and L3 classroom

\section{關鍵詞 無聊情緒·不/投入程度·無聊程度的波動·第二語言和第三語言課堂}

\section{Introduction}

The process of foreign language acquisition is influenced by a number of learner variables. While the majority of them (e.g., anxiety, learning strategies, and motivation) have been widely recognized and well-researched, boredom remains an underexplored area of language learning experience ${ }^{1}$. So far, $\mathrm{L} 2$ teachers and researchers have failed to give proper attention to this phenomenon which all too frequently is mistaken for laziness and associated with anxiety, depression, or personality factors [2]. Surprising though it may seem, boredom has been identified as the most intense and most frequently experienced student emotion [3, 4] that may inhibit the learning process and thus make it less efficient and less enjoyable. This accords with the present authors' observations which showed that some of their students were more distracted and unwilling to participate in classes than others. And that is what, alongside the paucity of research into boredom in the foreign language classroom, inspired them to investigate this negative experience from a mixed-methods perspective as well as look for possible ways of coping with it. It needs to be underlined that the concept of boredom is contrastively approached with regard to L2 and L3 acquisition, which is why the opening section briefly comments on the relationship between these two processes.

\section{Literature Review}

\section{L2 Acquisition Vs. L3 Acquisition}

Over the past two decades, the issue of third language acquisition (TLA) was subject to a rapidly growing number of studies that revealed it as qualitatively diverting from second language acquisition (SLA) ${ }^{2}[6]$ which deserves some attention before TLA is discussed. In general, it is understood as the process of learning a language other than one's mother tongue. SLA, at least partially, follows the route of first language acquisition; for example, one of the stages inherent in L1 acquisition is telegraphic speech which is similar to the L2 acquisitionspecific formulaic speech. L2 learning experience, usually based on a conscious assimilation of rules, is very different from an intuitive acquisition of the L1, which makes it more complex and unique $[7,8]$. That changes, however, when third language acquisition comes into play.

\footnotetext{
${ }^{1}$ Although overlooked and neglected in the L2 learning/teaching contexts, for many years, boredom has attracted the attention of researchers in the fields of psychology, educational psychology, and education [1].

${ }^{2}$ It should be noted that second language acquisition is also understood as the opposite of learning, in the sense that it is a subconscious process consisting in picking up the pieces of language in a way that resembles L1 acquisition [5]. 
Defined as a process of assimilating a non-native language by individuals who have already acquired or are still acquiring two other languages [9], TLA draws on and profits from the linguistic background knowledge composed of L1 and L2 knowledge [9-13]. More specifically, TLA may be facilitated by flexibility and enhanced metalinguistic awareness of the bilingual mind that is equipped with a greater repertoire of linguistic resources [14-17]. As a result of its dynamic interaction with background languages, the L3 is exposed to cross-linguistic influence whose patterns are more complex and varied than in the L2 $[18,19]$. TLA is also reported to be related to the affective factors, though this particular research area remains, to a large extent, a terra incognita. There are, however, some studies which demonstrate that the L2 can impact motivation to learn the L3 [20, 21]. The overall picture that emerges from TLA studies conducted to date shows it as depending on the learner's prior experience of acquiring other languages.

\section{The Definition and Typologies of Boredom}

Boredom, often referred to as one of the plagues of the modern world [22], can be defined as a negative emotion or psychological state associated with an inner sense of emptiness as well as lack of meaning and purpose resulting from an individual's perception of a learning environment as unstimulating [23, 24]. Bored students experience disengagement, dissatisfaction, and diminished interest in the activities that others may regard as involving, which makes this construct similar to anhedonia [2].

Boredom is an emotion with many intensities characterized within the typology ${ }^{3}$ dividing it into five subtypes [3]: indifferent boredom, calibrating boredom, searching boredom, reactant boredom, and apathetic boredom ${ }^{4}$. As for the first subtype, it is a pleasantly experienced emotion referring to students who are fatigued or withdrawn in a cheerful, relaxing way. When it comes to the second one, it relates to students who are dissatisfied with a situation they are in and want to change it but have no idea how to do it. It is a moderately unpleasant state that entails daydreaming about various off-topic things. The third subtype concerns an unpleasantly perceived urge to find something else to do which usually goes beyond the scope of a particular lesson or activity. Reactant boredom is a strongly unpleasant experience typical of individuals who are so determined to avoid it that they behave angrily and aggressively, trying to blame various external factors (e.g., the teacher, the materials or the task) for being disengaged. Finally, apathetic boredom is an exceptionally unpleasant experience of students whose positive and negative emotions are at equally low levels, meaning that their performance is accompanied by helplessness and dissatisfaction. Thus, although boredom is a definitely negative academic emotion hindering the language learning process, it is not always realized by students and not necessarily experienced in a frustrating and/or disagreeable way.

\section{Why Are Students Bored?}

Students are bored for various reasons that have been distinguished and elaborated on in a few models and theories worth paying attention to and thus briefly commented on in this

\footnotetext{
${ }^{3}$ There is another, more traditional typology of boredom that classifies it into two categories (state boredom and trait boredom) [25]. However, since it is less relevant to the present study, it will be skipped over.

${ }^{4}$ This typology has already been discussed in the present authors' earlier works (i.e., [26, 27]).
} 
subsection ${ }^{5}$. The under-stimulation model [29] stresses a scarcity of challenging stimuli that could activate students and encourage them to zestfully participate in classes. If students are taught by being told and memorizing rather than by being given problems to solve in their own trial-and-error way, their minds are likely to switch off. The forced-effort model [30] posits that boredom increases when the teacher imposes on students tasks which they find monotonous and unattractive but to which they have to devote a lot of cognitive effort. As a result, they become frustrated for the teacher acts as controller giving them few or no opportunities to take charge of their own learning. The attentional theory of boredom proneness [31,32] points to an individual's inability to self-regulate attention as one of the major causes of boredom. Inattention usually leads to memory lapses and off-topic thoughts which, in turn, reduce student engagement and willingness to take part in the activities that others regard as interesting. The control-value theory of achievement emotions $[33,34]$ reveals the experience of boredom as depending on students' appraisals of how much they can control a given task and what value they attach to it. In other words, the more they perceive themselves as being unable to take control over this task and the less value they attribute to it, the more likely they are to feel bored. Finally, the emotion theory $[31,35]$ indicates boredom as emerging from an individual's problems with identifying, accessing, and communicating their own feelings.

\section{Research on Boredom in the L2 Classroom}

As has already been stated, boredom is an area that has received very little attention in the L2 classroom; hence, there are only a few studies that address this issue, either in an indirect ([36-38]) or direct [1, 39-42] manner. Beerman and Cornjäger [36] investigated the perceptions of teenage German learners of L2 French concerning the teaching of this language with respect to joy, boredom, and anxiety experienced over the entire duration of study. Quantitative analysis showed that favorable perceptions of French language instruction were significantly and positively correlated with joy, while significantly and negatively correlated to boredom. In another quantitative study, Jean and Simard [37] examined the beliefs about the role of grammar instruction held by Québécois high school learners of English and French as an L2 as well as their teachers. The analysis of the data demonstrated that while negative perceptions of grammar teaching predominated, the participants were aware of the crucial role of this target language subsystem. The researchers concluded that perhaps the terms boring and effective should no longer be considered as a contradictory pair of qualifiers, at least when it comes to teaching grammar. Finally, it is worth mentioning Kormos and Csizér's quantitative study [38] aimed at investigating the causal relationships between motivational factors, self-regulation, and autonomous learning behavior in three groups of Hungarian high school students, university students, and adult learners of English as a foreign language. The results demonstrated that regardless of the subjects' age, their learning effort had a considerable effect on satiation control which is a self-regulatory strategy understood as the ability to combat boredom and find ways to make L2 learning activities interesting.

Using a mixed-methods approach, Chapman [1] examined the beliefs about this negative emotion manifested by learners of German as a foreign language and their

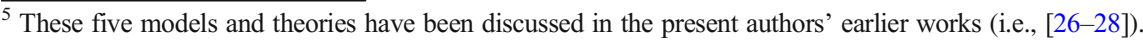


teachers. It transpired that the best predictor of boredom were learners' feelings towards the teacher which were much more influential than the nature of tasks and activities performed during the lessons. The next mixed-methods study, this time carried out by Kruk [40], aimed to examine fluctuations in the levels of boredom, motivation, and anxiety as experienced by the Polish students of English Philology during their visits to Second Life. Obtained results revealed changes in the levels of boredom and motivation. The patterns of boredom were shaped not only by the subjects' willingness to take advantage of SL for the purpose of communicating in English but also by their disappointment as a result of meeting aggressive or impolite interlocutors. Kruk and Zawodniak et al. [27] set out to both qualitatively and quantitatively investigate the relationship between the English Philology students' boredom proneness and a tendency to be bored in practical English classes. The authors referred to these two variables as positively correlated and indicated that the experience of boredom was time-dependent. Besides, a number of factors influencing student boredom were distinguished, such as either too easy or too difficult activities, the unchallenging and repetitive nature of activities, modes of work, and the teacher. In the study conducted by Palm et al. [42] in the Ecuadorian educational context, the focus was on examining methods of detecting boredom in the L2 classroom, including participant classroom observation, boredom logs, video recording, and the teacher's fieldwork journal. The obtained findings showed that observation instruments have to be modified and special pilot studies need to be designed, the final conclusion being that researchers should adopt a mixed-methods approach which would enable them to develop and validate instruments helping teachers gather information on how involving particular tasks are as well as on what they should do to increase the level of stimulation and challenge. In yet another study, Dumančić [39] explored the Croatian EFL teachers' experiences with classroom boredom. The qualitative analysis of the data revealed that teacher boredom was mainly caused by grammar tasks and uninteresting teaching content and that the most frequent manifestations of this negative emotion were of cognitive (e.g., lack of creativity and/or imagination) and motivational (e.g., loss of enthusiasm and/or interest) nature. As for emotion regulation strategies used by the teachers to overcome boredom, they primarily comprised attempts to introduce a different task and/or a physical activity (e.g., walking, stretching, participating in music-accompanied activities).

The above-outlined studies reveal some recurring factors that can be viewed as contributing to L2 student boredom and as, to a certain extent, confirming some of the previously described theories. Those factors include excessive teacher control [30], the lack of challenge [29], the inadequate sequencing of activities, goal-setting problems, a general tendency to be bored, and little usefulness of topics discussed/ subjects taught. Additionally, it is shown that boredom can also be experienced by teachers who have their own ways of coping with it and of avoiding a negative influence this state could have on their instructional quality. Since this overview of boredom-related research refers not only to EFL students but also to the ones learning German and French as an L2, it dawned on the authors that it might be interesting to look at this negative emotion also from the perspective of other languages. Given that L2 and L3 acquisition are, as has been signaled above, reported to be two distinct processes, the present study will comparatively examine L2 and L3 student boredom to see whether and how this experience differs in relation to both of these learning contexts. 


\section{The Study}

\section{Research Questions}

The study was guided by the following research questions:

1. How do levels of boredom experienced in learning English as an L2 change over the course of a semester and from one semester to another?

2. How do levels of boredom experienced in learning German as an L3 change over the course of a semester and from one semester to another?

3. Do levels of boredom experienced in learning English differ from the ones observed in learning German?

4. What are the main causes of boredom in learning English and German?

\section{Participants}

The participants of the study were 30 Polish university students (21 females and 9 males) majoring in English, enrolled in the second year of a three-year BA program. According to the university requirements, the participants attended a compulsory foreign language course in which they had been taught German ${ }^{6}$. They were on average $22.43(S D=4.75)$ years old. Their mean experience in learning English amounted to $12.60(S D=4.30)$ years and when it comes to German, it spanned over $8.77(S D=4.14)$ years. The subjects' average grade in the end-of-the-year examination in English was $3.66(S D=0.63)$ and their average semester grade in German equaled $3.57(S D=0.73$ ) on a scale from 2 to 5 , where 2 means "fail," 3 "satisfactory," 4 "good," and 5 "very good." The scale is typically used for assessment purposes in universities in Poland. Such evaluation was consistent with the students' own perception of their English proficiency, as evident in their self-assessment which was higher by 0.11 of a point on the same scale; however, their perception of their German ability was much lower and tantamount to 1.14. Details of the participants are shown in Table 1. It should also be noted that the winter semester in Polish universities typically begins in October and finishes at the end of January, whereas the summer semester typically starts at the end of February and terminates in the middle of June.

\section{Data Collection}

Drawing upon previous research on the motivation in retrospect (43), the language learning boredom in retrospect (LLBR) questionnaire was used in the present study to collect data (see Appendix). The aim of the questionnaire was to gather data concerning the experience of boredom in learning English and German from a retrospective perspective (i.e., over a span of three semesters). With this in mind, the study participants were asked to think back on their experience of boredom in learning English and German since the first semester at university. To be more specific, the students did reflect once for the three semesters at the end of the third semester. The students were asked to describe in what way and why they

\footnotetext{
${ }^{6}$ It needs to be indicated that German was the only additional language offered to the English majors.
} 


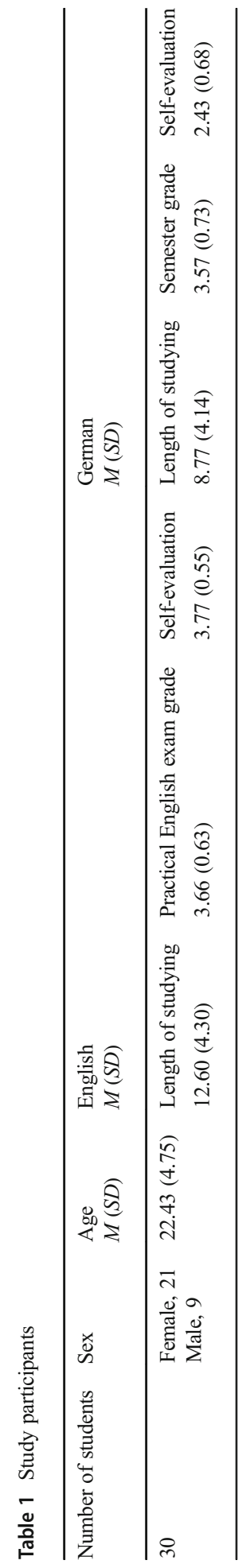


experienced boredom during the first, the second, and the third semester with their three different points in time (i.e., beginning, middle, and end). They were asked to consider a set of questions (e.g., Who caused boredom? What caused boredom? In what situations did you experience the most boredom?). These questions were formulated based on previous studies on boredom (e.g., [1, 26]) in which factors influencing boredom in learning a foreign language were identified. It was assumed that the factors obtained could be better distilled from the participants' real classroom-based experiences rather than from a set of closedended questionnaire items. The validity of the factors was, to some extent, ensured by their salience in the respondents' individual descriptions. The participants were also requested to rate the intensity of their feelings of boredom during each semester on a scale ranging from 1 (lowest) to 7 (highest). The value of Cronbach's alpha amounted to $.925^{7}$, which testifies to high internal consistency reliability of the instrument [44]. In addition, the tool contained a short demographic section to gain information on the participants' sex, age, prior language learning experience, practical English exam grade, last semester grade in German, and their self-evaluation of English and Germen proficiency. The questionnaire was completed by the students anonymously during class time.

To ward off potential misunderstandings or misinterpretations and ensure that the responses were indeed indicative of the students' experience of boredom, the instructions in the questionnaire were given in the students' mother tongue (i.e., Polish) and the students were asked to use Polish to write their answers.

\section{Analysis}

The collected data were subject to quantitative and qualitative analysis. The former concerns the numerical data rendered by self-ratings performed and indicated by the students on an L2/L3 boredom grid in the LLBR questionnaire, while the latter refers to the study participants' descriptions of their experience of boredom in learning the two foreign languages. The numerical data were used to calculate means and standard deviation values for L2/L3 boredom levels in the three semesters. Since some of the data obtained were not normally distributed, the levels of statistical significance were established by means of the nonparametric Mann-Whitney and Wilcoxon signed-rank tests. As regards the qualitative enquiry, each researcher carefully read the students' descriptions. The data were sorted out and coded into main themes by means of content analysis [44]. Any unclear or inconsistent issues were discussed and agreed upon by the two researchers. Moreover, the "quantising" technique ([45], p. 42) was utilized, which allows for the transformation of the qualitative data into quantitative data. Thus, the most frequently occurring items in the students' descriptions were recognized, marked, and counted.

\section{Results}

\section{Retrospective Fluctuations in Boredom Levels Throughout the Three Semesters}

As can be seen in Table 2 and in Fig. 1, the self-reported levels of the experience of boredom in learning L2 (English) and L3 (German) underwent some changes both

\footnotetext{
${ }^{7}$ English .857; German .963
} 
Table 2 The means and standard deviations for self-reported levels of L2 and L3 boredom in each semester

\begin{tabular}{llll}
\hline & & English & German \\
& & $M(S D)$ & \\
\hline 1st semester & Start & $2.43(1.52)$ & $2.87(1.96)$ \\
& Middle & $3.93(1.55)$ & $3.27(1.70)$ \\
End & $4.17(1.70)$ & $3.60(1.90)$ \\
Total & $3.51(1.26)$ & $3.24(1.74)$ \\
& Start & $3.20(1.63)$ & $3.27(1.84)$ \\
Mrd semester & Middle & $4.17(1.60)$ & $3.93(1.68)$ \\
& End & $4.40(1.77)$ & $4.27(1.96)$ \\
& Total & $3.92(1.43)$ & $3.82(1.69)$ \\
& Start & $2.90(1.67)$ & $3.67(1.90)$ \\
& Middle & $3.80(1.69)$ & $4.10(1.79)$ \\
& End & $4.53(1.93)$ & $4.60(2.08)$ \\
& Total & $3.74(1.46)$ & $4.12(1.79)$ \\
\hline
\end{tabular}

from one semester to another and during each semester. As far as the general levels of L2 boredom in each semester are concerned, they were the lowest in the first semester and the highest in the second semester. As regards the overall levels of L3 boredom, they were the lowest and the highest in the first semester and the third semester, respectively (see Table 2). It should be noted, however, that the Mann-Whitney test did not find any statistically significant differences in the experience of boredom in learning English and German between these two languages with their respective overall boredom semester levels $(p>0.05)$. In addition, the Wilcoxon signed-rank test revealed statistically significant differences in the levels of L2 boredom between the first semester and the second semester $(Z=-2.066, p=0.039)$ and in the levels of L3

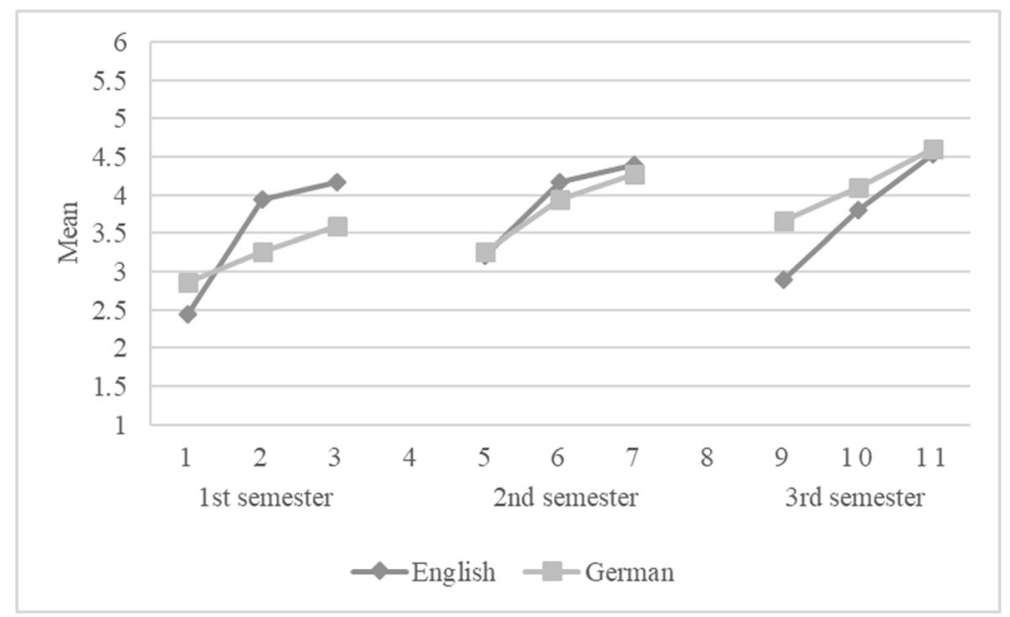

Fig. 1 Fluctuations in boredom during the first, second, and third semesters with their three different points in time (i.e., beginning, middle, and end) 
boredom between the first semester and the second semester $(Z=-2.927, p=0.003)$, the first semester and the third semester $(Z=-3.293, p=0.001)$ as well as the second semester and the third semester $(Z=-2.136, p=0.033)$.

When it comes to the changes in the experience of boredom in learning both English and German during each semester, they were always the lowest at the beginning and the highest at the end of them (see Fig. 1). In the case of English, the Wilcoxon signed-rank test found some statistically significant differences between different points in time (i.e., beginning, middle, and end) in: first semester: beginning $\rightarrow$ middle $(Z=-3.940, p=0.00)$, beginning $\rightarrow$ end $(Z=-$ 3.696, $p=0.00)$; second semester: beginning $\rightarrow$ middle $(Z=-3.575, p=0.00)$, beginning $\rightarrow$ end $(Z=-3.042, p=0.02)$; third semester: beginning $\rightarrow$ middle $(Z=-2.691, p=0.007)$, beginning $\rightarrow$ end $(Z=-3.599, p=0.000)$, middle $\rightarrow$ end $(Z=-2.720, p=0.007)$. As for German, the Wilcoxon signed-rank test revealed that all differences between different points in time in each semester were statistically significant: first semester: beginning $\rightarrow$ middle $(Z=-2.448, p=0.014)$, beginning $\rightarrow$ end $(Z=$ $-2.444, p=0.015)$, middle $\rightarrow$ end $(Z=-1.784, p=0.074)$; second semester: beginning $\rightarrow$ middle $(Z=-3.134, p=0.002)$, beginning $\rightarrow$ end $(Z=-2.940$, $p=0.003)$, middle $\rightarrow$ end $(Z=-2.140, p=0.032)$; third semester: beginning $\rightarrow$ middle $(Z=-2.565, p=0.010)$, beginning $\rightarrow$ end $(Z=-2.858, p=0.004)$, middle $\rightarrow$ end $(Z=-2.491, p=0.013)$. Finally, it should also be noted that the Mann-Whitney test did not find any statistically significant differences in the experience of boredom in learning English and German between these two languages during the three semesters with their three different points in time (i.e., beginning, middle, and end) $(p>0.05)$.

\section{Factors Responsible for Student Boredom}

\section{Factors Responsible for Student Boredom in Learning English}

Results of the qualitative analysis of the students' descriptions of their experience with boredom in English lessons during the three semesters were grouped into three thematic categories: lesson-related, teacher-related, and other. Overall, 228 references related to sources of boredom were discovered among the participants' responses.

Table 3 The number of references and their percentages

\begin{tabular}{|c|c|c|c|c|c|c|c|c|c|c|}
\hline \multirow[t]{2}{*}{ Factor } & \multicolumn{3}{|c|}{ 1st semester } & \multicolumn{3}{|c|}{ 2nd semester } & \multicolumn{3}{|c|}{ 3rd semester } & \multirow[t]{2}{*}{ Total } \\
\hline & Start & Middle & End & Start & Middle & End & Start & Middle & End & \\
\hline Lesson-related & $\begin{array}{l}7 \\
4.90 \%\end{array}$ & $\begin{array}{l}20 \\
13.99 \%\end{array}$ & $\begin{array}{l}19 \\
13.29 \%\end{array}$ & $\begin{array}{l}16 \\
11.19 \%\end{array}$ & $\begin{array}{l}20 \\
13.99 \%\end{array}$ & $\begin{array}{l}19 \\
13.29 \%\end{array}$ & $\begin{array}{l}14 \\
9.79 \%\end{array}$ & $\begin{array}{l}16 \\
11.19 \%\end{array}$ & $\begin{array}{l}12 \\
8.39 \%\end{array}$ & 143 \\
\hline Teacher-related & $\begin{array}{l}5 \\
7.58 \%\end{array}$ & $\begin{array}{l}10 \\
15.15 \%\end{array}$ & $\begin{array}{l}11 \\
16.67 \%\end{array}$ & $\begin{array}{l}6 \\
9.09 \%\end{array}$ & $\begin{array}{l}8 \\
12.12 \%\end{array}$ & $\begin{array}{l}6 \\
9.09 \%\end{array}$ & $\begin{array}{l}7 \\
10.61 \%\end{array}$ & $\begin{array}{l}6 \\
9.09 \%\end{array}$ & $\begin{array}{l}7 \\
10.61 \%\end{array}$ & 66 \\
\hline Other & $\begin{array}{l}1 \\
5.26 \%\end{array}$ & $\begin{array}{l}2 \\
10.53 \%\end{array}$ & $\begin{array}{l}2 \\
10.53 \%\end{array}$ & $\begin{array}{l}1 \\
5.26 \%\end{array}$ & $\begin{array}{l}3 \\
15.79 \%\end{array}$ & $\begin{array}{l}1 \\
5.26 \%\end{array}$ & $\begin{array}{l}1 \\
5.26 \%\end{array}$ & $\begin{array}{l}3 \\
15.79 \%\end{array}$ & $\begin{array}{l}5 \\
26.32 \%\end{array}$ & 19 \\
\hline
\end{tabular}




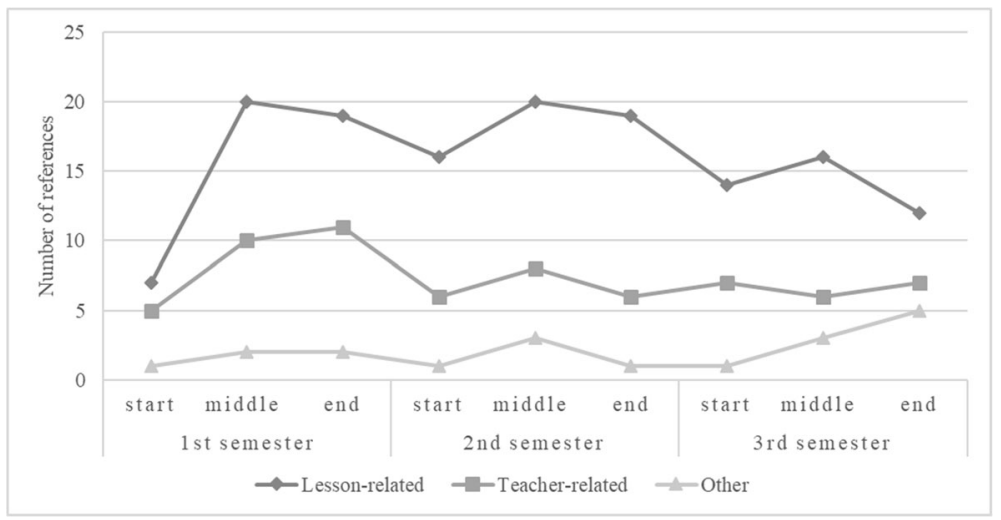

Fig. 2 Boredom in learning English during the first, second, and third semesters with their three points in time (i.e., start, middle, and end)

Lesson-Related Factors When it comes to the first category (i.e., lesson-related factors), it constituted the largest source of boredom (143 indications in total). As shown in Table 3 and Fig. 2, the lesson-related factors were the most pronounced in the middle and at the end of the first and the second semesters, respectively. Conversely, they were the least significant at the beginning of the first semester and at the end of the third semester.

The analysis of the data revealed that the study participants experienced boredom during English classes due to repeatability of the language material, their uselessness and not involving content (e.g., topics and language tasks), predictability of lessons/ tasks and the level of difficulty (i.e., some language activities were too easy or too difficult for the students). In addition to this, some participants were bored with lessons during which they had to do a set of tasks related to their practical exam. The following excerpts illustrate these points:

- (...) we almost didn't learn anything new, the same material was repeated over and over again. The classes became dull. The practical English classes were some of the most boring ones.

- In this semester we spent a lot of class time on studying for the practical English exam. At some point, it became boring, because in some practical classes we discussed the same things.

- I felt bored, the classes were monotonous and I felt tired and frustrated at the end of the semester. It was because I perceived the practical English classes and my presence there as useless. I could use the time spent there better preparing for the approaching exams.

- The smallest problem was with speaking and the biggest with listening. Listening to long recordings during listening classes put students into a lethargy, kept them between being alive and asleep.

- The same work scheme made practical classes boring and monotonous. It was always clear what to expect on each day.

- Practical English classes didn't contribute to my knowledge. I got the feeling that their level was the same as in the first semester, no noticeable progress and boredom as a result. 
Teacher-Related Factors Teacher-related factors comprised the second major source of boredom (66 references in total). As illustrated in Fig. 2 and shown in Table 3, they were the most frequently mentioned in the middle and at the end of the first semester and in the middle of the second semester. The analysis of the data showed that the experience of boredom was caused by the way of conducting lessons (e.g., lack of involvement and energy on the part of teachers), teaching methods/techniques used by teachers, and some personal and/or physical teacher characteristics (e.g., monotonous voice). This is illustrated by the following comments:

- In my opinion, our teachers were not very involved in conducting classes.

- (...) some teachers conducted their classes in a very monotonous way, without energy.

- Boredom was caused by teachers, lessons were monotonous, no teacher-student interaction.

- I started to get bored in some classes sometimes because of the teacher and his monotonous voice.

- No change. Some teachers used the same method which didn't involve students.

Other Factors The other category comprised 19 references (see Fig. 2 and Table 3 ) and included such factors as class time, the weather, and overall work overload. These are exemplified in the following:

- Classes on Friday.

- The level of boredom reached the zenith, a lot of work, approaching exams.

- (...) the weather made me experience boredom during classes.

\section{Factors Responsible for Student Boredom in Learning German}

The qualitative analysis of the participants' descriptions of their experience of boredom during German lessons throughout the three semesters yielded the following four categories: lesson-related factors, reluctance to learn German, people-related factors, and other factors. In general, 173 references related to sources of boredom were discovered among the students' responses.

Lesson-Related Factors As far as the first category (i.e., lesson-related factors) is concerned, it encompassed 100 references in total. As indicated by the data in Table 4 and Fig. 3, this source of boredom was the highest at the end of the second semester and in the middle of the third semester.

The analysis of the data demonstrated that the feelings of boredom were induced by similar lessons (i.e., they were "the same all the time"), not interesting topics, repeatability of language material, and the level of difficulty of tasks (i.e., they were too difficult). Moreover, the lessons covered a lot of material which was difficult to process 
Table 4 The number of references and their percentages

\begin{tabular}{|c|c|c|c|c|c|c|c|c|c|c|}
\hline \multirow[t]{2}{*}{ Factor } & \multicolumn{3}{|c|}{ 1st semester } & \multicolumn{3}{|c|}{ 2nd semester } & \multicolumn{3}{|c|}{ 3rd semester } & \multirow[t]{2}{*}{ Total } \\
\hline & Start & Middle & End & Start & Middle & End & Start & Middle & End & \\
\hline Lesson-related & $\begin{array}{l}4 \\
4 \%\end{array}$ & $\begin{array}{l}8 \\
8 \%\end{array}$ & $\begin{array}{l}10 \\
10 \%\end{array}$ & $\begin{array}{l}13 \\
13 \%\end{array}$ & $\begin{array}{l}12 \\
12 \%\end{array}$ & $\begin{array}{l}15 \\
15 \%\end{array}$ & $\begin{array}{l}10 \\
10 \%\end{array}$ & $\begin{array}{l}15 \\
15 \%\end{array}$ & $\begin{array}{l}13 \\
13 \%\end{array}$ & 100 \\
\hline $\begin{array}{l}\text { Reluctance to } \\
\text { learn } \\
\text { German }\end{array}$ & $\begin{array}{l}7 \\
16.28 \%\end{array}$ & $\begin{array}{l}5 \\
11.63 \%\end{array}$ & $\begin{array}{l}4 \\
9.30 \%\end{array}$ & $\begin{array}{l}4 \\
9.30 \%\end{array}$ & $\begin{array}{l}5 \\
11.63 \%\end{array}$ & $\begin{array}{l}4 \\
9.30 \%\end{array}$ & $\begin{array}{l}5 \\
11.63 \%\end{array}$ & $\begin{array}{l}5 \\
11.63 \%\end{array}$ & $\begin{array}{l}4 \\
9.30 \%\end{array}$ & 43 \\
\hline People-related & $\begin{array}{l}3 \\
14.29 \%\end{array}$ & $\begin{array}{l}4 \\
19.05 \%\end{array}$ & $\begin{array}{l}4 \\
19.05 \%\end{array}$ & $\begin{array}{l}2 \\
9.52 \%\end{array}$ & $\begin{array}{l}2 \\
9.52 \%\end{array}$ & $\begin{array}{l}2 \\
9.52 \%\end{array}$ & $\begin{array}{l}1 \\
4.76 \%\end{array}$ & $\begin{array}{l}2 \\
9.52 \%\end{array}$ & $\begin{array}{l}1 \\
4.76 \%\end{array}$ & 21 \\
\hline Other & - & $\begin{array}{l}2 \\
22.22 \%\end{array}$ & $\begin{array}{l}1 \\
11.11 \%\end{array}$ & $\begin{array}{l}1 \\
11.11 \%\end{array}$ & - & - & $\begin{array}{l}1 \\
11.11 \%\end{array}$ & $\begin{array}{l}2 \\
22.22 \%\end{array}$ & $\begin{array}{l}2 \\
22.22 \%\end{array}$ & 9 \\
\hline
\end{tabular}

for some participants due to their backlog. This is illustrated by the following comments:

- Still the classes were not very interesting. We repeated the material from previous semesters.

- After some time it turned out that the classes looked the same (...). It caused boredom and discouragement again.

- Nothing changed. The level of difficulty increased as opposed to the level of my knowledge of German.

- The classes were still not adjusted to the level of our proficiency. They were very difficult and they lasted for hours.

Reluctance to Learn German As mentioned above, boredom in learning German was also caused by some of the participants' reluctance to learn this language. As can be seen from Fig. 3 and Table 4, this factor was quite a major source of boredom (it

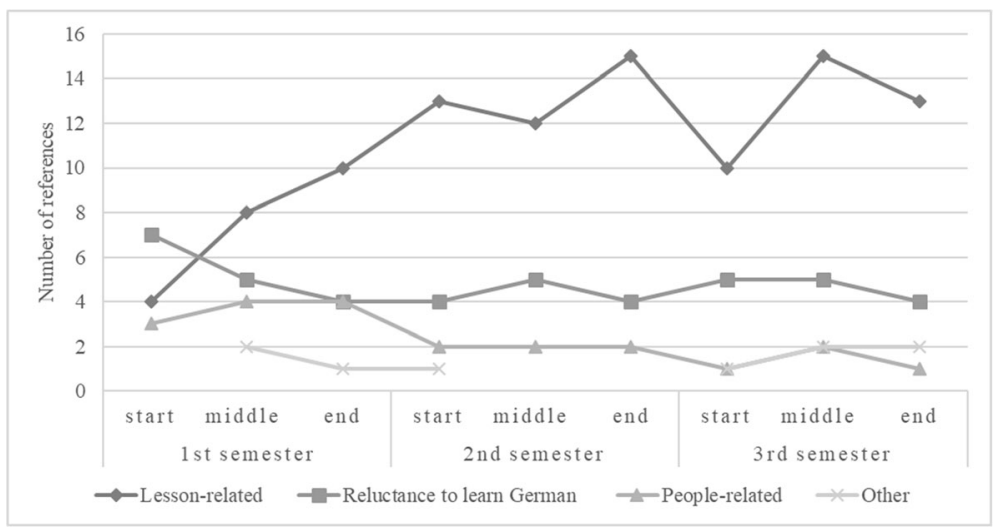

Fig. 3 Boredom in learning German during the first, second, and third semesters with their three points in time (i.e., start, middle, and end) 
included 43 references in total) throughout the three semesters. This is evidenced by the following comments gleaned from the students' descriptions of their experience of boredom:

- (...) when I chose the English philology, I thought I'd make myself free from studying two subjects: mathematics and German but I succeeded in just one. My reluctance to learn this language and the lack of motivation to do this was the main and the most important factor causing boredom.

- Boredom was caused by my unwillingness to study German (...)

People-Related Factors People-related factors comprised yet another source of boredom. Overall, they were mentioned 21 times (see Fig. 3 and Table 4). According to some participants, boredom was caused by too demanding teachers ("the teacher was too demanding"), teaching methods and techniques used by him/her ("methods and techniques used by the teacher didn't change at all"), and peers ("boredom was caused by both peers and the teacher").

Other Factors Last but not least, boredom was invoked by class time. This was mentioned nine times (see Fig. 3 and Table 4):

- The main problem was that the classes took place once a week, one after another, and in the evening. After the whole day, I felt tired and this made me bored.

- It's the time of classes and their length. After all day at university, it's difficult to concentrate.

\section{Discussion}

The study set out to answer four questions, three of which pertained to the quantitatively measured levels of boredom experienced in the L2 and L3 classroom, while the final, fourth question referred to the qualitatively examined reasons for boredom in those two learning situations. As far as the former issue is concerned, obtained data show that boredom levels in L2 and L3 learning were the lowest at the outset and the highest towards the end of each of the three semesters, which more or less echoes the present authors' previous studies [40, 41]. It may indicate that the students brought into both the L2 and L3 classroom some expectations and needs for exploration, manipulation, or stimulation [46] which were not fulfilled. At the beginning of a new semester, they may just have looked forward to some dose of novelty and fresh incentives to boost their participation in the activities proposed by their teacher(s). It seems to be the most likely reason for the subjects' initial engagement which was being gradually replaced with frustration and helplessness in response to a more and more discouraging learning environment. Concerning the experience of boredom extended over the course of all the three semesters, the findings reveal that in the L2 classroom the subjects found themselves least and most bored in the first and second semester, respectively, while in the L3 classroom, they felt least and most disengaged in the first and third semester, respectively. It might be assumed that the students were 
concerned with passing the approaching practical English exam, which made them more active than in the case of L3 classes involved in their work in the third semester, regardless of how much they disliked it. To put it in other words, the respondents' complaints about the monotony of L2 classes, stemming from "the same work scheme" connected with preparations for the practical English exam, did not fully prevent them from considering the advantages of investing some effort in task performance. In all likelihood, the students were instrumentally oriented [47] towards the L2, meaning that in the third semester their willingness to participate in the English language activities grew due to a practical reason connected with fulfilling exam requirements. Thus, for one thing, the respondents apparently treated the L2 exam as a necessary evil and, for another, they looked upon it as a step forward enabling them to continue education and make some plans for the future. Conversely, the L3 experience of boredom was constantly growing to reach its peak in the final third semester, which, given the respondents' comments, implies their helplessness and/or frustration mixed with inability to see prospective strengths of attending the L3 course.

As regards the reasons for L2 and L3 boredom, the analysis of student comments led the authors to distinguish two major categories, namely teachers in relation to L2 learning and classes in relation to both L2 and L3 learning. When it comes to the former category, the respondents pointed to lack of teacher engagement as contributing to their boredom. Another two important factors within this category refer to teacher reliance on the same method(s) throughout the whole course and the scarcity of teacher-student interactions. Concerning the category of classes, most of the factors mentioned by the subjects were common to L2 and L3 learning contexts. More precisely, they indicated the repetitive, monotonous nature of classes and not really interesting topics as increasing their disengagement. The next cause of boredom is connected with the inappropriate sequencing of activities which were either too easy (L2) or too difficult (L3). Yet another factor that can be interpreted as a precursor to boredom is lack of meaning as the respondents could not find a purpose for participating in L2 and L3 activities thus arranged. This is in line with Beermann and Crönjager's [36] findings indicating the usefulness of taught material as a possible deterrent to boredom (cf. $[48,49])$. One more reason for student disengagement, this time related only to the L3 classroom, is the lack of motivation to learn German which was not the respondents' favorite subject and which some of them, as has been shown in their comments, would like to avoid at any expense. ${ }^{8}$ Special attention should be paid to the relationship between a negative attitude to German and the students' self-assessment of proficiency in that language which was exceptionally low. It may imply that apart from presumably acting as a mental block against actively participating in classes, the unwillingness to learn German negatively affected the students' levels of situational and task self-esteem [50, 51]. Finally, it is noteworthy that, as indicated in the respondents' descriptions, boredom was also influenced by purely external factors (e.g., class time and the weather) not in the least degree connected with the two languages, thus leaving no room for teacher initiative or intervention.

The causes of L2 and L3 student boredom just described can be linked to three of the theoretical models touched upon in the literature review part of this paper. Accordingly, the under-stimulation model [29] can be referred to at this point since the students were in a state

\footnotetext{
${ }^{8}$ Although the students stressed their "unwillingness to study German," they did not elaborate on this issue. It is, therefore, worth adding that in Poland German is not among the most enthusiastically learned languages. There are some historical reasons for this, but another, perhaps more important, thing is that it is perceived as a language that is grammatically more complex than English.
} 
of decreased arousal resulting from exposure to predictable and thus unchallenging stimuli that did not encourage them to learn by discovery and problem solving. It is also worth indicating the forced-effort model [30] as the respondents felt compelled to do teacherimposed tasks whose monotony and repeatability were very discouraging for them. Finally, there is a relationship between the control-value theory of achievement emotions [33, 34] and the subjects' awareness that they did not have control over the choice of topics and tasks performed in class as well as that they did not appreciate what was going on in the L2 and L3 learning contexts. Interestingly, the respondents made no comments on their own contribution to the unpleasant experience of boredom nor did they reflect on the opportunities for beating the frustrating monotony of classes. It can be, therefore, presumed that the students were mainly influenced by reactant boredom [3], blaming a number of factors, and at the same time being far from self-criticism.

\section{Conclusions and Pedagogical Implications}

The study has revealed boredom as a construct undergoing numerous fluctuations whose character and intensity depend on a number of factors for the most part pertaining to the teacher (L2), classes (L2 and L3), and reluctance to learn the language (L3). The changing and very often unpredictable character of boredom observed in those two learning situations as well as the rapidity of those changes give grounds for categorizing this construct as a complex dynamic system nested within and overlapping many other systems constituting the language learning environment (cf. [52]). No significant between-group differences were observed, which can be accounted for by the same type of learning experience (foreign languages) guided by similar overall purposes (developing language skills and subsystems). At the same time, it has to be asserted that the average level of boredom was higher in the L2 classroom with the exception of the third semester. In both learning contexts, the students' experience of boredom was the lowest at the very beginning of each semester and the highest towards its end, which shows that their initial enthusiasm waned, giving way to the disappointment with monotonous, repetitive activities imposed by the teacher and therefore leaving little room for their own choice and initiative. Additionally, the L3 boredom was shaped by the respondents' general unwillingness to learn the German language, which seemed to increase their helplessness and frustration pronounced in the comments and probably transferred to their behaviors.

The definition of boredom that emerges from the present study shows it as a state of disengagement caused by the repetitive nature of teacher-controlled activities (L2 and L3), the students' negative attitude to the language (L3), their inability or reluctance to cope with this negative situation (L2 and L3), and little teacher involvement (L2). As revealed by this definition, both students and teachers can make a contribution to boredom in the L2 classroom, which is why it is worthwhile to consider how the two parties can effectively deal with it. As for students, they need a more insightful reflection on their negative emotions (cf. $[31,35]$ ) so that they could come up with some boredom-coping solutions. When it comes to teachers, change and variety should be considered alongside the appropriate sequencing of activities, alternative lesson 
plans, respect for students' interests, and, perhaps most significantly, professional passion and engagement. Since the respondents complained about monotonous activities, it would be beneficial to promote active learning which draws on any teaching tool that makes one engaged in the learning process [53]. Students will learn actively if they are exposed to open-ended tasks encompassing brainstorming, argumentative debates, role play, reasoning gap, or dictogloss. To sum up, as shown by research data, the experience of boredom in L2 and L3 learning was similar at some points (the monotony of classes, the lack of challenge, the level of difficulty) and distinct at others (preparation for the exam, unsuccessful teacher and peer cooperation, attitudinal factors). However, in both cases, boredom appeared to be a problematic phenomenon that frustrated and disappointed students, thus calling for the teacher's skillful intervention, some aspects of which have just been pinpointed.

Although the authors believe that the study has enhanced the understanding of the experience of boredom over a longer period of time (i.e., several months), they are fully aware of its limitations that need to be highlighted. Firstly, the procedure that required the participants to think back on their boredom for learning English and German has to be mentioned. The study that examined the individuals' retrospective reflections on their experience of boredom in the two contexts depended entirely on the respondents' more or less distant memories that may have been incomplete and may have been, at least to a certain extent, burdened with hindsight bias. Secondly, what has to be indicated is a small number of participants, which reduces the validity of generalizing the findings. Thirdly, potential flaws in the data collection tool also should be taken into consideration. All these shortcomings show that it necessary to conduct further research into the experience of boredom from a retrospective point of view. Future studies, for instance, should center on groups of language learners from different countries and draw on datagathering instruments that should be subject to constant improvement and adjustment to particular contexts in which they are carried out.

Acknowledgments The authors would like to express their gratitude to the anonymous reviewers and editors for their useful comments. We also thank dr. Chengchen Li for translating the title and abstract into Chinese.

\section{Compliance with Ethical Standards}

Conflict of Interest The authors declare that they have no conflict of interest.

\section{Appendix. Boredom in Learning English and German in Retrospect (Translated from Polish)}

Male $\square$ Female $\square$ Age

The purpose of this questionnaire is to collect data concerning boredom in learning English and German. Please try to describe in what way and why you experienced boredom in learning these two foreign languages with their three different points in time (i.e., the beginning, middle, and end 
of each semester). Please consider the following questions: (1) Who caused boredom (teachers, peers, etc.)? (2) What caused boredom (language tasks, teaching materials, teaching methods, etc.)? (3) In what situations did you experience most boredom? (4) Other? Next, try to rate the levels of boredom in each semester on a scale ranging from 1 (no boredom) to 7 (the highest boredom) with their three different points in time (i.e., beginning, middle, and end).

\section{English}

$1^{\text {st }}$ semester

Beginning:

Middle:

End:

* Now please rate the level of your boredom in learning English in the first semester on a scale of 1 (no boredom) to 7 (the highest boredom)

Beginning Middle End

\section{$2^{\text {nd }}$ semester}

Beginning:

Middle:

End:

*Now please rate the level of your boredom in learning English in the second semester on a scale of 1 (no boredom) to 7 (the highest boredom)

Beginning Middle End

\section{$3^{\text {rd }}$ semester}

Beginning:

Middle:

End:

* Now please rate the level of your boredom in learning English in the third semester on a scale of 1 (no boredom) to 7 (the highest boredom)

Beginning $\quad$ Middle End

\section{German}

$1^{\text {st }}$ semester

Beginning:

Middle:

End:

* Now please rate the level of your boredom in learning German in the first semester on a scale of 1 (no boredom) to 7 (the highest boredom) 


\section{$2^{\text {nd }}$ semester}

Beginning:

Middle:

End:

*Now please rate the level of your boredom in learning German in the second semester on a scale of 1 (no boredom) to 7 (the highest boredom)

Beginning Middle End

\section{$3^{\text {rd }}$ semester}

Beginning:

Middle:

End:

* Now please rate the level of your boredom in learning German in the third semester on a scale of 1 (no boredom) to 7 (the highest boredom)

Beginning Middle End

Open Access This article is licensed under a Creative Commons Attribution 4.0 International License, which permits use, sharing, adaptation, distribution and reproduction in any medium or format, as long as you give appropriate credit to the original author(s) and the source, provide a link to the Creative Commons licence, and indicate if changes were made. The images or other third party material in this article are included in the article's Creative Commons licence, unless indicated otherwise in a credit line to the material. If material is not included in the article's Creative Commons licence and your intended use is not permitted by statutory regulation or exceeds the permitted use, you will need to obtain permission directly from the copyright holder. To view a copy of this licence, visit http://creativecommons.org/licenses/by/4.0/.

\section{References}

1. Chapman, K. E. (2013). Boredom in the German foreign language classroom (Unpublished doctoral dissertation). Madison: University of Wisconsin-Madison.

2. Macklem, G. L. (2015). Boredom in the classroom: addressing student motivation, self-regulation, and engagement in learning. New York: Springer.

3. Goetz, T., Frenzel, A. C., Hall, N. C., Nett, U. E., Pekrun, R., \& Lipnevich, A. A. (2014). Types of boredom: an experience sampling approach. Motivation and Emotion, 38(3), 401-419.

4. Pekrun, R., Goetz, T., Daniels, L. M., Stupnisky, R. H., \& Perry, R. P. (2010). Boredom in achievement settings: exploring control-value antecedents and performance outcomes of a neglected emotion. Journal of Educational Psychology, 102(3), 531-549.

5. Krashen, S. D., \& Terrell, T. D. (1995). The natural approach: language acquisition in the classroom. Hemel Hempstead: Phoenix ELT.

6. Hammarberg, B. (2018). L3, the tertiary language. In A. Bonnet \& P. Siemund (Eds.), Foreign language education in multilingual classrooms (pp. 127-150). Edinburgh: Edinburgh University Press.

7. Ellis, R. (2000). The study of second language acquisition. Oxford: Oxford University Press.

8. Klein, E. C. (2006). Second vs. third language acquisition: Is there a difference? Language Learning, 45(3), 419-466.

9. Cenoz, J. (2003). The successive effect of bilingualism on third language acquisition: a review. International Journal of Bilingualism, 7, 71-87. 
10. Cenoz, J. (2001). The effect of linguistic distance, L2 status and age on crosslinguistic influence in third language acquisition. In J. Cenoz, B. Hufeisen, \& U. Jessner (Eds.), Cross-linguistic influence in third language acquisition: psycholinguistic perspectives (pp. 8-20). Clevedon: Multilingual Matters.

11. Hammarberg, B. (2001). Roles of L1 and L2 in L3 production and acquisition. In J. Cenoz, B. Hufeisen, \& U. Jessner (Eds.), Cross-linguistic influence in third language acquisition: psycholinguistic perspectives (pp. 21-41). Clevedon: Multilingual Matters.

12. Hammarberg, B. (2010). The languages of the multilingual: some conceptual and terminological issues. International Review of Applied Linguistics in Language Teaching, 48, 91-104.

13. Hufeisen, B. (2005). Multilingualism: linguistic models and related issues. In B. Hufeisen \& R. J. Fouser (Eds.), Introductory readings in L3 (pp. 31-45). Tübingen: Stauffenburg Verlag.

14. Cenoz, J. (2013). The influence of bilingualism on third language acquisition: focus on multilingualism. Language Teaching, 46, 71-86.

15. García Mayo, M. P. (2012). Cognitive approaches to L3 acquisition. International Journal of English Studies, 12(1), 129-146.

16. Hammarberg, B., \& Williams, S. (2009). A study of third language acquisition. In B. Hammarberg (Ed.), Processes in third language acquisition (pp. 17-27). Edinburgh: Edinburgh University Press.

17. Thomas, J. (1988). The role played by metalinguistic awareness in second and third language learning. Journal of Multilingual and Multicultural Development, 9, 235-246.

18. De Angelis, G., \& Dewaele, J. M. (2011). New trends in crosslinguistic influence and multilingualism research. Bristol: Multilingual Matters.

19. Falk, Y., \& Bardel, C. (2010). The study of the role of the background languages in third language acquisition: the state of the art. International Review of Applied Linguistics in Language Teaching, 48, $185-220$.

20. Henry, A. (2010). Gender differences in L2 motivation: a reassessment. In S. Davies (Ed.), Gender gap: causes, experiences and effects (pp. 81-101). New York: Nova Science Publishers.

21. Henry, A. (2011). Why can't I be doing this in English instead? An interview study of the impact of L2 English on girls' and boys' L3 selves. In C. Maree \& K. Satoh (Eds.), Proceedings of the 6th Biennial International Gender and Language Association Conference (pp. 126-139). Tokyo: International Gender and Language Association.

22. Spacks, P. M. (1995). Boredom: the literary history of a state of mind. Chicago: University of Chicago Press.

23. Fahlman, S. A. (2009). Development and validation of the Multidimensional State Boredom Scale (Unpublished doctoral dissertation). Ottawa: York University.

24. Goldberg, Y. K., Eastwood, J. D., LaGuardia, J., \& Danckert, J. (2011). Boredom: an emotional experience distinct from apathy, anhedonia, or depression. Journal of Social and Clinical Psychology, 30(6), 647-666.

25. Vogel-Walcutt, J., Fiorell, L., Carper, T., \& Schatz, S. (2012). The definition, assessment, and mitigation of state boredom within educational settings: a comprehensive review. Educational Psychology Review, 24(1), 89-111.

26. Kruk, M., \& Zawodniak, J. (2018). Boredom in practical English language classes: insights from interview data. In L. Szymański, J. Zawodniak, A. Łobodziec, \& M. Smoluk (Eds.), Interdisciplinary views on the English language, literature and culture (pp. 177-191). Zielona Góra: Uniwersytet Zielonogórski.

27. Zawodniak, J., Kruk, M., \& Chumas, J. (2017). Towards conceptualizing boredom as an emotion in the EFL academic context. Konin Language Studies, 5(4), 425-441.

28. Zawodniak, J., \& Kruk, M. (2019). Boredom in the English language classroom: an investigation of three language learners. Konin Language Studies, 7(2), 197-214.

29. Larson, R. W., \& Richards, M. H. (1991). Boredom in the middle school years: blaming schools versus blaming students. American Journal of Education, 99(4), 418-433.

30. Hill, A. B., \& Perkins, R. E. (1985). Towards a model of boredom. British Journal of Psychology, 76(2), 235-240.

31. Eastwood, J. D., Cavaliere, C., Fahlman, S. A., \& Eastwood, A. E. (2007). A desire for desires: boredom and its relation to alexithymia. Personality and Individual Differences, 42(6), 1035-1045.

32. Harris, M. B. (2000). Correlates and characteristics of boredom proneness and boredom. Journal of Applied Social Psychology, 30, 576-598.

33. Pekrun, R. (2006). The control-value theory of achievement emotions: assumptions, corollaries, and implications for educational research and practice. Educational Psychology Review, 18(4), 315-341. 
34. Tulis, M., \& Fulmer, S. M. (2013). Students' motivational and emotional experiences and their relationship to persistence during academic challenge in mathematics and reading. Learning and Individual Differences, 27, 35-46.

35. Eastwood, J. D., Frischen, A., Fenske, M. J., \& Smilek, D. (2012). The unengaged mind: defining boredom in terms of attention. Perspectives on Psychological Science, 7(5), 482-495.

36. Beerman, C., \& Cornjäger, H. (2011). Die Rolle der Fachtwerteschätzung für Freude, Langewile und Angst im Fach Französisch: Eine memhrebenenanalytische Längsschnittstudie über die Sekundarstufe I unter Verwendung von Piecewise Growth Modellen. Zeitschrift für Interkulturellen, 16(2), 18-34.

37. Jean, G., \& Simard, D. (2011). Grammar teaching and learning in L2: necessary, but boring? Foreign Language Annals, 44(3), 467-494.

38. Kormos, J., \& Csizér, K. (2014). The interaction of motivation, self-regulatory strategies, and autonomous learning behavior in different learner groups. TESOL Quarterly, 48(2), 275-299.

39. Dumančić, D. (2018). Investigating boredom among EFL teachers. ExELL (Explorations in English Language and Linguistics), 6(1), 57-80.

40. Kruk, M. (2016). Variations in motivation, anxiety and boredom in learning English in Second Life. The EUROCALL Review, 23(1), 25-39.

41. Kruk, M., \& Zawodniak, J. (2017). Nuda a praktyczna nauka języka angielskiego. Neofilolog, 49(1), 115-131.

42. Palm, H., Poveda, M. F., \& Harutyanyan, L. (2018). Attending boredom in the foreign language learning classroom: approaches, challenges and solutions. In M. Simons \& T. F. H. Smits (Eds.), Language education and emotions (pp. 30-37). Antwerp: University of Antwerp.

43. Kruk, M., \& M., Mahmoodzadeh (2018). Motivational dynamics of language learning in retrospect: results of a study. Hungarian Journal of Applied Linguistics, 18(2), 1-22.

44. Dörnyei, Z. (2007). Research methods in applied linguistics. Oxford: Oxford University Press.

45. Miles, M. B., \& Huberman, M. A. (1994). Qualitative data analysis: an expanded sourcebook (2nd ed.). Thousand Oaks: Sage.

46. Ausubel, D. (1968). Educational psychology: a cognitive view. New York: Holt, Rinehart and Winston.

47. Gardner, R. C., \& Lambert, W. E. (1972). Attitudes and motivation: second language learning. New York: Newbury House.

48. Hulleman, C. S., \& Harackiewicz, J. M. (2009). Making education relevant: increasing interest and performance in high school science classes. Science, 32, 1410-1412.

49. Yeager, D. S., Henderson, M., D’Mello, S., Paunesku, D., Walton, G. M., Spitzer, B. J., \& Duckworth, A. L. (2014, March). Boring but important: a self-transcendent purpose for learning fosters academic self-regulation. Retrieved from https://web.stanford.edu/ gwalton/home/Welcome_files/Yeager_etal_ inpress.pdf

50. Arnold, J. (2011). Attention to affect in language learning. Anglistik: International Journal of English Studies, 22(1), 11-22.

51. Rubio, F. (2007). Self-esteem and foreign language learning. Newcastle: Cambridge Scholars Publishing.

52. Larsen-Freeman, D. (2016). Classroom-oriented research from a complex systems perspective. Studies in Second Language Learning and Teaching, 6(3), 377-393.

53. Prince, M. (2004). Does active learning work? A review of the research. Journal of Engineering Education, 93(3), 223-231. 